\title{
PENGARUH IMPLEMENTASI KEBIJAKAN TERHADAP KINERJA PENGELOLAAN KEUANGAN NAGARI DI KABUPATEN PASAMAN
}

\author{
Indrilita Maulidya \\ Jurusan Ilmu Administrasi Publik, Fakultas Ilmu Sosial, Universitas Negeri Padang \\ indrilitamaulidya1@gmail.com
}

\begin{abstract}
This study aims to determine the effect of policy implementation on the performance of nagari apparatus in nagari financial management in Pasaman Regency. This research was motivated by the lack of implementation of policies on nagari financial management in Pasaman Regency. This study used a quantitative research method conducted on 12 nagari in Pasaman Regency with a population of 96 consisting of walinagari, nagari secretary, three heads of affairs and three section heads. While the number of samples as many as 88 respondents were determined using the Slovin formula. In this study data collection used a Likert Scale with data collection techniques using the Proportionate Stratified Random Sampling technique. The results of this study show that partially the communication sub-variables have an effect of 20.5\%, sub-variables of resources by 2.6\%, sub-disposition variables by $17.1 \%$ and sub-variables of birourism structure by $13.5 \%$ on the performance of nagari financial management. While simultaneously the policy implementation variables provide a significant influence on the performance of nagari financial management in Pasaman District with a simultaneous influence of $12.8 \%$.
\end{abstract}

Keywords: Policy Implementation, Nagari Financial Management

\section{Pendahuluan}

Sejak dikeluarkannya Undang-Undang Nomor 6 tahun 2014 tentang Desa semua mata tertuju kepada desa yang disebabkan pemberian dana desa oleh pemerintah yang jumlahnya makin besar. Hal ini menunjukan bahwa pemerintah serius untuk memajukan desa. Agar tujuan pemerintah untuk memajukan desa dapat terwujud maka tidak bisa hanya mengandalkan ketersediaan regulasi saja namun juga dibutuhkan partisipasi dari stakeholders terkait dan ketersediaan dana desa. Untuk mencapai kemajuan desa maka diperlukan para kepala desa dan perangkat desa yang mempunyai kapasitas dalam pengelolaan keuangan desa yang telah dilimpahkan pemerintah. Oleh karena itu mereka harus memahami dan mengerti isi kebijakan tentang desa sehingga pengelolaan keuangan desa tidak akan mengalami masalah serius ke depannya.

Masalah pengelolaan keuangan desa masih menjadi tantangan yang perlu diperhatikan oleh pemerintah. Menurut ketentuan umum pasal 1 ayat (6) Permendagri Nomor 20 Tahun 2018 pengelolaan keuangan desa adalah keseluruhan kegiatan yang mencakup perencanaan, pelaksanaan, penatausahaan pelaporan dan pertanggungjawaban keuangan desa. Secara regulatif semua keuangan desa ini akan terdokumentasi dalam bentuk APB Desa/Nagari yang pengelolaannya mengikuti berbagai petunjuk dari peraturan perundang-undangan. Maka hal ini berarti pemerintah desa atau kepala desa sebagai kuasa penguna anggaran tidak boleh sembarangan mengelola keuangan desa. Selanjutnya dalam ketentuan umum Peraturan Bupati Kabupaten Pasaman Nomor 2 tahun 2016 Tentang Tata Cara Pembagian, Penetapan, Rincian Dana Desa Setiap Nagari dan Perioritas Penggunaan Dana Desa di Kabupaten Pasaman Tahun Anggaran 2016 pasal 1 ayat (17) dijelaskan bahwa pengelolaan keuangan nagari adalah keseluruhan kegiatan yang meliputi perencanaan, pelaksanaan, penatausahaan, pelaporan, pertanggungjawaban, dan pengawasan keuangan nagari. 
Ada beberapa masalah dalam pengelolaan keuangan nagari selama ini yaitu keterbatasan regulasi khusus tentang nagari yang tidak cukup membantu wali nagari dan perangkatnya dalam pengelolaan keuangan nagari. Hal ini terlihat jelas dari adanya keterlambatan dan kesulitan pemerintahan nagari dalam penyusunan perencanaan kegiatan dan keuangan nagari. Salah satu contohnya adalah Nagari Simpang Tonang Kecamatan Duo Koto Kabupaten Pasaman yang terlambat melaporkan Anggaran Pendapatan dan Belanja Desa (APBNagari), sehingga proses pencairan Alokasi Dana Desa juga terlambat dan tidak terealisasikan tepat waktu. M.Ikhsan Kepala Dinas Pemberdayaan Masyarakat mengatakan bahwa Alokasi Dana Desa yang berasal dari APBN itu masuk ke kas daerah pada bulan April lalu. Namun baru terealisasikan ke kas nagari pada bulan Juni kemarin. Hal itu disebabkan karena Anggaran Pendapatan dan Belanja Desa (APBNagari) banyak yang terlambat melaporkannya (BakiNews.com 24 Juli 2017, diakses pada 20 September 2018).

Selanjutnya adanya mantan Walinagari Koto Kaciak Kecamatan Bonjol Kamisurhadi, periode 2008-2014 yang terbukti melakukan tindak pidana korupsi terkait dana Kredit Mikro Nagari (KMN) tahun 2009. Kepala Seksi Pidana Khusus Kejari Pasaman Erik Eriadi menyebutkan bahwa dana KMN tersebut cair sebesar Rp 300 juta yang digunakan tersangka untuk kepentingan pribadinya (AntaraSumbar 26 Oktober 2017, diakses pada 22 September 2018). Senada dengan kasus tersebut Walinagari Padang Gelugur Saharrudin, juga terbukti melakukan tindak pidana korupsi terkait pendistribusian beras miskin (Raskin) tahun 2012. "Kasus ini berawal dari pendistribusian raskin ke-13 pada desember 2012 lalu, sebelum didistribusikan tokoh masyarakat Nagari Padang Gelugur menggelar pertemuan terkait pendistribusian Raskin. Hasil dari musyawarah tersebut adalah sebanyak $26.700 \mathrm{~kg}$ Raskin dibagikan untuk 1.784 keluarga tersebut diserahkan kepada tersangka untuk dijual kepada pihak ketiga dan hasil penjualan disepakati akan digunakan untuk pembangunan hingga memenuhi kebutuhan nagari, namun kenyataannya hasil penjualan beras tersebut sekitar Rp107 juta tetapi yang diterima pihak pemerintahan nagari hanya sekitar Rp 43 juta dan sisa Rp 63 juta tidak dibayarkan pembeli atau pihak ketiga untuk pembayaran utang pribadi tersangka kepada pembeli." tambah Kepala Seksi Pidana Khusus Kejari Pasaman Erik Eriadi. (Hariansinggalang.co.id 11 Juli 2017, diakses pada 22 September 2018).

Berdasarkan hasil wawancara penulis dengan Sekretaris Nagari Limo Koto pada tanggal 22 Maret 2019 beliau mengatakan bahwa permasalahan dalam pengelolaan keuangan nagari yaitu terdapat tumpang tindihnya aturan yang harus diikuti oleh pemerintah nagari dan banyaknya program lintas sektoral yang dibebankan kepada pemerintah nagari sehingga program prioritas nagari menjadi terganggu akibat tekanan program dari pemerintah yang lebih tinggi. Selain itu berdasarkan wawancara penulis dengan Bapak Zulfahmi selaku Walinagari Koto Kaciak pada tanggal 25 Maret 2019 beliau mengatakan bahwa masalah yang dihadapi dalam pengelolaan keuangan nagari diantaranya yaitu sering terjadi perubahan peraturan tentang pengelolaan keuangan nagari dan lambatnya informasi perubahan tersebut sampai ke pemerintah nagari. Menurut beliau masih kurangnya sosialisasi dari pemerintahan yang lebih tinggi juga menjadi permasalahan dalam pengelolaan keuangan nagari. Selanjutnya, berdasarkan hasil temuan dilapangan penulis menemukan kurang jelasnya Peraturan Bupati Nomor 3 Tahun 2017 tentang Perubahan Atas Peraturan Bupati Nomor 7 Tahun 2015 tentang Pedoman Pengelolaan Keuangan Pemerintahan Nagari, dimana peraturan yang sudah direvisi tersebut tidak melampirkan secara utuh keseluruhan isi peraturan tersebut akan tetapi hanya melampirkan perubahan dari peraturan yang sebelumnya saja.

Berdasarkan latar belakang masalah yang telah diuraikan di atas, maka penulis telah melakukan penelitian di Kabupaten Pasaman tentang Pengaruh Implementasi Kebijakan terhadap Kinerja Perangkat Nagari dalam Pengelolaan Keuangan Nagari di Kabuapten Pasaman. Penelitian ini merupakan intisari dari hasil penelitian skripsi dan bagian dari penelitian payung yang dilakukan oleh Syamsir (2017) dengan judul Model Pembinaan 
Aparatur Pemerintahan Nagari dalam Pengelolaan Keuangan Nagari di Kabupaten Tanah Datar. Adapun rumusan masalah dalam penelitian ini adalah "Apakah terdapat pengaruh Implementasi Kebijakan terhadap Kinerja Perangkat Nagari dalam Pengelolaan Keuangan Nagari di Kabupaten Pasaman?’.

\section{Tinjauan Kepustakaan}

\section{Implementasi Kebijakan dan Kinerja}

Nugroho (2009:494) mengatakan bahwa implementasi kebijakan publik pada dasarnya adalah cara agar sebuah kebijakan dapat mencapai tujuan. Selain itu menurut Tacjhan (2006:24) implementasi kebijakan adalah suatu aktivitas yang bertalian dengan penyelesaian dan/atau pelaksanaan suatu kebijakan publik yang telah disetujui dan ditetapkan dengan menggunakan sarana dan prasarana yang telah disediakan untuk mencapai tujuan kebijakan tersebut.

Mengacu pada teori Edward III (dalam Agustino, 2014: 149) terdapat 4 (empat) variabel yang sangat mempengaruhi keberhasilan implementasi kebijakan yaitu :

1) Komunikasi, untuk mengukur keberhasilan variabel ini terdapat 3 (tiga) indikator yang dapat digunakan yaitu : a) Transmisi, maksudnya yaitu penyaluran komunikasi yang baik akan dapat menghasilkan suatu implementasi yang baik pula. Seringkali terjadi masalah dalam penyaluran komunikasi yaitu salah satunya adalah adanya salah pengertian (miskomunikasi) yang disebabkan banyaknya tingakatan organisasi yang harus dilalui dalam proses komunikasi sehingga apa yang diharapkan tidak dapat tercapai. b) Kejelasan, maksudnya adalah komunikasi yang diterima oleh pelaksana kebijakan harus jelas dan tidak membingungkan atau tidak ambigu. c) Konsistensi, maksudnya adalah perintah yang diberikan dalam pelaksanaan suatu komunikasi harus konsisten dan jelas untuk ditetapkan atau dijalankan. Bila perintah yang diberikan sering berubah-ubah maka dapat menimbulkan keambiguan bagi pelaksana di lapangan.

2) Sumberdaya, sumberdaya utama dalam implementasi kebijakan adalah staff. Diperlukan staff yng ahli dan mampu dalam mengimplementasikan suatu kebijakan. Kedua adalah informasi, informasi berhubungan dengan cara melaksanakan kebijakan, implementator harus mengetahui apa yang harus mereka lakukan disaat mereka diberi perintah untuk melakukan tindakan. Ketiga adalah wewenang, maksudnya adalah bahwa pada umumnya kewenangan harus bersifat formal agar perintah dapat dilaksanakan secara efektif. Maka kewenangan merupakan otoritas atau legitimasi bagi para semua pelaksana dalam melaksanakan kebijakan yang ditetapkan secara politik. Keempat adalah fasilitas, dalam implementasi kebijakan fasilitas fisik merupakan faktor yang penting. Tanpa adanya fasilitas pendukung atau sarana dan prasarana maka implementasi kebijakan tersebut tidak akan berhasil.

3) Disposisi, maksudnya adalah sikap dari pelaksana kebijakan yang merupakan faktor penting dalam pendekatan mengenai pelaksanaan kebijakan publik, implementator atau pelaksana kebijakan yang dipilih dan diangkat tidak hanya harus mengetahui apa yang harus dilaksanakannya tetapi haruslah memiliki kemampuan untuk melaksanakan kebijakan tersebut.

4) Struktur Birokrasi, untuk mengukur keberhasilan struktur birokrasi dalam implementasi kebijakan terdapat 2 (dua) indikator yang dapat digunakan yaitu : Pertama yaitu Standard Operational Procedure (SOP), merupakan sebuah prosedur kerja ukuran dasar. SOP adalah suatu kegiatan rutin yang memungkinkan para pegawai atau pelaksana kebijakan untuk bisa melaksanakan bentuk kegiatan-kegiatannya pada setiap harinya sesuai dengan standar yang sudah ditetapkan. Kedua yaitu fragmentasi, merupakan upaya penyebaran 
tanggungjawab kegiatan-kegiatan atau aktivitas-aktivitas pegawai diantara beberapa unit kerja.

Kinetika energi kerja merupakan kepanjangan dari kinerja yang berasal dari Bahasa Inggris yaitu performance yang diartikan dalam bahasa indonesia sebagai performa atau kinerja. Kinerja adalah keluaran (output) yang dihasilkan oleh fungsi-fungsi dan/atau indikator-indikator suatu pekerjaan dan/atau profesi dalam waktu tertentu (Wirawan, 2009 : 5). Menurut (Edison, Emron, Yhony Anwar, 2016) kinerja adalah hasil atau capaian dari suatu proses yang diukur selama periode waktu tertentu berdasarkan ketentuan dan/atau kesepakatan yang telah ditetapkan sebelumnya. Berdasarkan uraian tersebut maka dapat disimpulkan bahwa kinerja pegawai adalah hasil yang dicapai oleh seseorang atau seorang pegawai baik secara kuantitas maupun kualitas berdasarkan tugas atau tanggungjawab yang diberikan kepadanya. Menurut (Syamsir dan Baiyulis, 2018) uraian dari kinerja mencakup tiga komponen penting yaitu tujuan, ukuran dan penilaian yang mana komponen penentuan tujuan merupakan strategi untuk meningkatkan kinerja dan memberikan arah serta mempengaruhi perilaku kerja pegawai sesuai dengan yang seharusnya di harapkan organisasi trsebut tehadap setiap pegawai.

Davis (dalam Mulyadi, 2015: 63) menyebutkan bahwa pecapaian kinerja dipengaruhi oleh beberapa faktor yaitu : 1) Faktor kemampuan, secara psikologis kemampuan pegawai terdiri dari kemampuan potensi (IQ). Jika seorang pegawai atau karyawan memiliki IQ sekitar 110-120 (di atas rata-rata) dan memiliki pendidikan yang sesuai untuk jabatannya serta terampil dalam mengerjakan pekerjaan sehari-hari maka dengan demikian pegawai tersebut akan mudah mencapai kinerja yang diharapkan. Oleh karena itu penempatan kerja pegawai pegawai harus sesuai dengan kemampuan dan keahlian yang dimilikinya. 2) Faktor motivasi, terbentuk dari sikap (attitude) dari seorang pegawai dalam menghadapi sitiuasi atau keadaan tertentu. motivasi merupakan kondisi yang mengarahkan diri pegawai untuk mencapai tujuan organisasi atau tujuan kerja.

Kinerja diartikan sebagai keberhasilan dan/atau kesuksesan dari suatu tindakan, tugas atau operasi yang dilakukan oleh seseorang, kelompok orang atau organisasi. Dengan demikian kinerja dapat merujuk pada hasil (outcome), keluaran (output), dan/atau pencapaian (accomplishment). Jika dihubungkan dengan kebijakan, maka kinerja pada suatu kebijakan diartikan sebagai suatu gambaran atau hasil mengenai tingkat pencapaian implementasi dalam mewujudkan tujuan dan sasaran suatu kebijakan baik itu berupa hasil kebijakan (policy outcome) maupun keluaran kebijakan (policy output) (Purwanto dan Sulistyastuti, 2012: 99100).

Menurut Sumaryadi (dalam Rochmat, 2016) efektivitas implementasi kebijakan pada akhirnya akan memberikan dampak terhadap kinerja, baik secara individu, kelompok, maupun organisasi. Maka dari itu, pelaksanaan kebijakan disuatu organisasi atau instansi akan berdampak atau berpengaruh kepada kinerja pegawainya. Sehingga kinerja pegawai akan mempengaruhi kinerja kelompok dan pada akhirnya akan mempengaruhi kinerja organisasi atau instansi secara keseluruhan.

Banyak penelitian yang telah dilakukan oleh para peneliti tentang pengaruh implementasi kebijakan terhadap kinerja karyawan atau pegawai. Adapun temuan penelitian yang mendukung teori tersebut adalah hasil penelitian Haryadi (2015), yang mendapatkan hasil penelitian bahwa secara simultan maupun parsial variabel implementasi kebijakan secara empirik telah memberikan pengaruh besar terhadap kinerja pelayanan publik di Pemerintah Kota Bandung. Selanjutnya hasil penelitian yang dilakukan oleh Kartini (2016) yang mendapatkan hasil penelitian bahwa secara parsial maupun simultan implementasi kebijakan memberikan pengaruh yang signifikan terhadap kinerja pegawai pada Kementerian Agama Kota Bandung. Berdasarkan hasil penelitian tersebut dapat diketahui bahwa secara 
operasional implementasi kebijakan dipandang sangat penting dan sangat berpengaruh terhadap kinerja pegawai dalam pelayanan publik.

\section{Pengelolaan Keuangan Desa/Nagari}

Di Indonesia pengelolaan keuangan desa diatur dalam Permendagri Nomor 20 Tahun 2018 tentang Pengelolaan Keuangan Desa Pasal 1 Ayat 6 yang menjelaskan bahwa pengelolaan keuangan desa adalah keseluruhan kegiatan yang meliputi perencanaan, pelaksanaan, penatausahaan, pelaporan dan pertanggungjawaban keuangan desa yang dilakukan secara:

1) Transparansi, yaitu prinsip keterbukaan yang memungkinkan masyarakat untuk dapat mengetahui dan mendapatkan akses seluas-luasnya terhadap informasi mengenai pengelolaan keuangan desa/nagari atau APBDesa/nagari.

2) Akuntabilitas, yaitu prinsip kewajiban untuk mempertanggungjawabkan pengelolaan dan pengendalian sumberdaya serta pelaksanaan dari kebijakan yang telah dipercayakan kepadanya dalam rangka pencapaian tujuan yang telah ditetapkan.

3) Partisipatisi, yaitu prinsip dari pengelolaan keuangan desa yang harus memberikan ruang seluas-luasnya kepada masyarakat secara aktif terlibat dalam setiap tahapan proses pengelolaan keuangan desa.

4) Tertib dan disiplin anggaran, yaitu prinsip pengelolaan keuangan desa yang mengandung makna bahwa APBDesa harus dikelola secara tepat guna dan tapat waktu yang didukung dengan bukti-bukti administratif yang dapat dipertanggungjawabkan serta berpedoman kepada peraturan yang berlaku.

\section{Metode Penelitian}

Dalam penelitian ini peneliti menggunakan metode penelitian kuantitatif dengan analisis datanya menggunakan data numerik atau angka yang diolah menggunakan metode statistik. Populasi dalam penelitian ini adalah sebanyak 96 aparatur nagari yang ada di 12 nagari di tiga kecamatan di Kabupaten Pasaman. Sedangkan jumlah sampel yang digunakan adalah sebanyak 88 responden yang ditentukan berdasarkan rumus slovin dengan menggunakan teknik Proportionate Stratified Random Sampling.

Pada penelitian ini pengumpulan data peneliti menggunakan Skala Likert yang menggunakan empat pilihan jawaban yaitu: sangat tidak setuju, tidak setuju, setuju dan sangat setuju. Kemudian data yang diperoleh dianalisis menggunakan teknik regresi linear berganda. Selain itu data yang diperoleh juga akan di uji menggunakan uji asumsi klasik dan akan mendapatkan gambaran umum kedua variabel dengan menggunakan mean, frekuensi dan TCR (Tingkat Capaian Responden).

\section{Hasil Penelitian dan Pembahasan}

\section{Hasil Penelitian}

Sebagaimana yang telah dijabarkan dalam bagian pendahuluan di atas, penelitian ini bertujuan untuk menjawab lima pertanyaan penelitian yang terdapat pada rumusan masalah yaitu: pertama, kedua, ketiga, dan keempat, apakah terdapat pengaruh secara parsial dari aspek komunikasi, sumberdaya, disposisi, dan struktur birokrasi (sebagai sub variabel implementasi kebijakan) terhadap kinerja perangkat nagari dalam pengelolaan keuanagn nagari di Kabupaten Pasaman? Untuk menjawab pertanyaan penelitian tersebut dapat dilihat dari hasil pengujian regresi pada tabel di bawah ini. 
Tabel 1. Pegaruh Secara Parsial Sub Variabel Komunikasi, Sumberdaya, Disposisi dan Struktur Birokrasi terhadap Kinerja Pengelolaan Keuangan Nagari

\begin{tabular}{lcccc}
\hline Sub Variabel & R & R Square & $\begin{array}{c}\text { Adjusted R } \\
\text { Square }\end{array}$ & Sig. \\
\hline Komunikasi & $.463^{\mathrm{a}}$ & .214 & .205 & $.000^{\mathrm{a}}$ \\
Sumberdaya & $.194^{\mathrm{a}}$ & .038 & .026 & $.070^{\mathrm{a}}$ \\
Disposisi & $.425^{\mathrm{a}}$ & .181 & .171 & $.000^{\mathrm{a}}$ \\
Struktur Birokrasi & $.381^{\mathrm{a}}$ & .145 & .135 & $.000^{\mathrm{a}}$ \\
\hline a. Predictors: (Constant),Sub Variabel & Implementasi & Kebijakan & (Komunikasi, & Sumberdaya, \\
Disposisis, Implementasi Kebijakan Struktur Birokrasi) & & & \\
b. Dependent Variable: Pengelolaan Keuangan Nagari & &
\end{tabular}

Sumber: Hasil Pengolahan Data 2019

Berdasarkan tabel di atas dapat diketahui bahwa untuk sub variabel komunikasi menghasilkan nilai Adjusted $R$ Square sebesar 0,205 yang berarti bahwa komunikasi berpengaruh terhadap pengelolaan keuangan nagari sebesar 20,5\%. Sementara sisanya dipengaruhi oleh variabel lain sebesar $79,5 \%$. Selanjutnya untuk sub variabel sumberdaya menghasilkan nilai Adjusted $R$ Square sebesar 0,026 yang berarti bahwa sumberdaya berpengaruh terhadap pengelolaan keuangan ngari sebesar 2,6\%. Sementara sisanya dipengaruhi oleh variabel lain sebesar 97,4\%. Berikunya untuk sub variabel disposisi memiliki nilai Adjusted $R$ Square sebesar 0,171 yang berarti bahwa disposisi berpengaruh terhadap pengelolaan keuangan nagari adalah sebesar $17,1 \%$. Sementara sisanya dipengaruhi oleh variabel lain sebesar 82,9\%. Sedangkan untuk sub variabel struktur birokrasi menghasilkan nilai Adjusted $R$ Square sebesar 0,135 yang berarti bahwa sruktur birokrasi berpengaruh terhadap pengelolaan keuangan nagari sebesar 13,5\%. Sementara sisanya dipengaruhi oleh variabel lain $86,5 \%$. Selain itu, bila diperhatikan hasil uji anova pada hasil signifikansi tabel di atas pengaruh menunjukan angka $0,000^{\text {a }}$ untuk tiga sub variabel dan $0,070^{\text {a }}$ untuk satu variabel. Ini berarti bahwa kebenaran kesimpulan hasil uji regresi tersebut dapat dipercaya sampai $100 \%$.

Selanjutnya rumusan masalah kelima yang ingin dijawab peneliti dalam penelitian ini adalah: Apakah terdapat pengaruh implementasi kebijakan (yang mencakup keempat sub variabel: komunikasi, sumberdaya, disposisi dan struktur birokrasi secara simultan) terhadap kinerja perangkat nagari dalam pengelolaan keuangan nagari di Kabupaten Pasaman? Secara ringkas, dapat diketahui dari hasil analisis data temuan penelitian yang disajikan pada tabel di bawah ini.

Tabel 2. Pengaruh Variabel Implementasi Kebijakan (Komunikasi, Sumberdaya, Disposisi, dan Struktur Birokrasi secara simultan) terhadap Kinerja Perangkat Nagari dalam Pengelolaan Keuangan Nagari

\begin{tabular}{cccccc}
\multicolumn{5}{c}{ Model Summary $^{\mathbf{b}}$} \\
\hline Model & $\mathbf{R}$ & R Square & $\begin{array}{c}\text { Adjusted R } \\
\text { Square }\end{array}$ & $\begin{array}{c}\text { Std. Error of the } \\
\text { Estimate }\end{array}$ & Durbin-Watson \\
\hline 1 & $.372^{\mathrm{a}}$ & .138 & .128 & .34448 & 1.341 \\
\hline
\end{tabular}

a. Predictors: (Constant), Implementasi Kebijakan Komunikasi, Implementasi Kebijakan Sumberdaya, Implementasi Kebijakan Disposisis, Implementasi Kebijakan Struktur Birokrasi

b. Dependent Variable: Pengelolaan Keuangan Nagari

Sumber: Hasil Pengolahan Data 2019 
Tabel 3. Hasil Uji Anova (F) Pengaruh Implementasi Kebijakan terhadap Kinerja Perangkat Nagari dalam Pengelolaan Keuangan Nagari

\begin{tabular}{clccccc}
\hline \multicolumn{1}{l}{} & Model & Sum of Squares & df & Mean Square & F & Sig. \\
\hline \multirow{2}{*}{1} & Regression & 1.639 & 1 & 1.639 & 13.810 & $.000^{\mathrm{b}}$ \\
& Residual & 10.206 & 86 & .119 & & \\
& Total & 11.844 & 87 & & & \\
\hline
\end{tabular}

a. Predictors: (Constant),Sub Variabel Implementasi Kebijakan (Komunikasi, Sumberdaya, Disposisis, Implementasi Kebijakan Struktur Birokrasi)

b. Dependent Variable: Pengelolaan Keuangan Nagari

Sumber: Hasil Pengolahan Data 2019

Berdasarkan Tabel hasil uji Anova di atas dapat diketahui bahwa nilai Adjusted $R$ Square yang diperoleh dari analisis regresi mengahsilkan nilai sebesar 0,128 yang berarti besarnya pengaruh variabel implementasi kebijakan yang mencakup empat sub variabel (komunikasi, sumberdaya, disposisi dan sumberdaya secara simultan) terhadap kinerja perangkat nagari dalam pengelolaan keuangan nagari adalah sebesar $12,8 \%$. Sementara sisanya 87,2\% dipengaruhi oleh faktor lain. Jika diperhatikan hasi uji Anova pada Tabel 3 di atas dapat pula dilihat bahwa hasil signifikansi pengaruh menunjukan angka $0,000^{\mathrm{b}}$ yang artinya kebenaran kesimpulan hasil uji regresi ini dapat dipercaya sampai $100 \%$.

\section{Pembahasan}

Hasil penelitian tentang pengaruh implementasi kebijakan terhadap kinerja perangkat nagari dalam pengelolaan keuangan nagari di Kabupaten Pasaman telah membuktikan bahwa secara simultan terdapat pengaruh implementasi kebijakan pengelolaan keuangan nagari terhadap kinerja perangkat nagari dalam pengelolaan keuangan nagari di Kabupaten Pasaman. Namun secara parsial dari empat sub variabel implementasi kebijakan, yaitu komunikasi, sumberdaya, disposisi dan struktur birokrasi terdapat satu sub variabel yang tidak berpengaruh terhadap kinerja perangkat nagari dalam pengelolaan keuangan nagari yaitu sub variabel sumberdaya. Secara simultan pengaruh implementasi kebijakan terhadap kinerja perangkat nagari dalam pengelolaan keuangan nagari di Kabupaten Pasaman menghasilkan angka signifikansi 0,000 dengan nilai Adjusted $R$ Square sebesar 0,128. Sehingga dapat dikatakan bahwa kontribusinya terhadap pengelolaan keuangan nagari adalah sebesar $12,8 \%$. Sedangkan nilai $\mathrm{R}$ yang dihasilkan adalah sebesar $.372^{\mathrm{a}}$ yang berarti bahwa kekuatan variabel implementasi kebijakan pengelolaan keuangan nagari terhadap kinerja perangkat nagari dalam pengelolaan keuangan nagari di Kabupaten Pasaman adalah sebesar 37,2\%. Dengan demikian, berdasarkan uraian tersebut dapat disimpulkan bahwa secara simultan implementasi kebijakan pengelolaan keuangan nagari memiliki pengaruh yang signifikan terhadap kinerja perangkat nagari dalam pengelolaan keuangan nagari di Kabupaten Pasaman. Akan tetapi secara pasrial yaitu sub variabel sumberdaya tidak memiliki pengaruh yang signifikan terhadap pengelolaan keuangan nagari.

Selanjutnya, hasil uji secara parsial pengaruh sub variabel komunikasi (X1), sumberdaya (X2), disposisi (X3), dan struktur birokrasi (X4) terhadap pengelolaan keuangan nagari. Untuk sub variabel komunikasi menghasilkan angka signifikansi 0,000 dengan nilai Adjusted $R$ Square sebesar 0,205 (20,5\%). Untuk sub variabel sumberdaya menghasilkan angka signifikansi 0,070 dengan nilai Adjusted $R$ Square sebesar 0,026 (2,6\%). Untuk sub variabel disposisi menghsilkan angka signifikansi sebesar 0,000 dengan nilai Adjusted $R$ Square sebesar 0,171 (17,1\%). Dan untuk sub variabel struktur birokrasi menghasilkan angka signifikansi sebesar 0,000 dengan nilai nilai Adjusted $R$ Square sebesar 0,135 (13,5\%). 
Dengan memperhatikan hasil dari penelitian ini dapat dipahami bahwa hasil penelitian ini dapat memperkuat dan ikut membuktikan teori-teori dan temuan penelitian yang telah dilakukan, seperti yang dikemukakan oleh Sumaryadi (dalam Rochmat, 2016) yang berpendapat bahwa efektivitas implementasi kebijakan pada akhirnya akan memberikan dampak ataupun pengaruh terhadap kinerja, baik secara individu, kelompok, maupun organisasi. Selanjutnya hasil dari penelitian ini juga dapat memperkuat dan membuktikan teori yang dikemukakan oleh Grindle (dalam Haryadi, 2015) yang berpendapat bahwa suatu implementasi kebijakan bertujuan untuk mencapai kinerja pemerintah. Senada dengan hal tersebut hasil penelitian ini juga dapat membuktikan dan memperkuat teori yang dikemukakan oleh Wibawa et al (1994) (dalam Tahir, 2014: 92) yang menjelaskan bahwa implementasi kebijakan bertujuan untuk menetapkan arah supaya tujuan kebijakan publik dapat direalisasikan sebagai hasil ataupun kinerja dari kegiatan pemerintah.

Hasil penelitian ini juga mendukung dan berkaitan dengan penelitian sebelumnya yang dilakukan oleh Haryadi (2015), Kartini (2016) yang mendapatkan hasil penelitian bahwa variabel implementasi kebijakan berpengaruh signifikan terhadap kinerja pegawai dalam mewujudkan kulaitas pelayanan publik.

\section{Penutup}

Berdasarkan hasil penelitian dan pembahasan yang telah dipaparkan dia atas, maka dapat disimpulkan bahwa sub-sub variabel implementasi kebijakan secara parsial yang berpengaruh signifikan terhadap kinerja perangkat nagari dalam pengelolaan keuangan nagari di Kabupaten Pasaman yaitu sub variabel komunikasi (X1), sub variabel disposisi (X3) dan sub variabel struktur birokrasi (X4). Sementara itu sub variabel sumberdaya (X2) tidak berpengaruh signifikan terhadap kinerja perangkat nagari dalam pengelolaan keuangan nagari di Kabupaten Pasaman. Secara simultan variabel implementasi kebijakan memiliki pengaruh yang signifikan terhadap kinerja perangkat nagari dalam pengelolaan keuangan nagari di Kabupaten Pasaman yaitu sebesar 12,8\%.

Berdasakan hasil penelitian dan kesimpulan diatas maka penulis mengemukakan saran-saran sebagai berikut:

1. Hasil penelitian ini menunjukan bahwa variabel implementasi kebijakan berpengaruh signifikan terhadap kinerja perangkat nagari dalam pengelolaan keuangan nagari di Kabupaten Pasaman dengan kontribusi sebesar 12,8\%. Sementara sisanya 87,2\% yang belum dimaksimalkan oleh Perangkat Nagari Kabupaten Pasaman. Dengan demikian disarankan kepada setiap perangkat nagari agar lebih memahami maksud dan tujuan dari pengimplementasian kebijakan pengelolaan keuangan nagari. Apabila perangkat nagari kurang memahami maksud dan tujuan dari kebijakan pengelolaan keuangan nagari tersebut maka kinerja pengelolaan keuangan nagari tidak tercapai. Selanjutnya disarankan kepada Pemerintah Daerah Kabupaten Pasaman agar lebih memberikan perhatian yang serius terhadap implementasi kebijakan pengelolaan keuangan nagari sehingga permasalahan dalam pengelolaan keuangan nagari tidak terjadi.

2. Peneliti menyadari bahwa hasil dari penelitian ini masih memiliki kelemahan tertentu, maka untuk itu diharapkan kepada penelliti selanjutnya untuk lebih menyempurnakan penelitian ini dengan melibatkan berbagai variabel lain yang mungkin juga dapat berpengaruh terhadap kinerja pengelolaan keuangan nagari di Kabupaten Pasaman. 


\section{DAFTAR PUSTAKA}

Baiyulis dan Syamsir. (2018). Pengaruh Kepuasan Kerja terhadap Kinerja Perangkat Nagari dalam Pengelolaan Keuangan Nagari di Kecamatan Tarab dan Salimpaung. Journal of Education on Social Science. 2(2). p73-85. (http://jess.ppj.unp.ac.id/index.php/JESS/article/view/148/60 )

Baki News. (2017). ADD Kabupaten Pasaman Tahun 2017 Semakin Meningkat. Berita Online. $\quad$ (http://bakinews-online.com/berita/detail/add-kab-pasaman-tahun-2017semakin-meningkat). Diakses pada tanggal 20 September 2018.

Emron Edison, Yhony Anwar, Imas Komariyah. (2016). Manajemen Sumber Daya Manausia; strategi dan perubahan dalam rangka meningkatkan kinerja pegawai dan organisasi. Bandung : Alfabeta.

Erwan Agus Purwanto dan Dyah Ratih Sulistyastuti. (2015). Implementasi Kebijakan Publik; konsep dan aplikasinya di Indonesia. Yogyakarta : Gava Media.

Harian Singgalang. (2017). Masalah Penjualan Raskin Walinagari di Pasaman ditahan Jaksa. $B$ Berita Online. (http://hariansinggalang.co.id/masalah-penjulan-raskin-walinagari-dipasaman-ditahan-jaksa/amp). Diakses pada tanggal 22 September 2018.

Leo Agustino. (2014). Dasar-dasar Kebijakan Publik. Bandung : Alfabeta.

Mulyadi. (2015). Manajemen Sumber Daya Manusia. Bogor : In Media.

Riant Nugroho. (2009). Public Policy. Jakarta : Elex Media Komputindo.

Riko Saputra. (2017). Kejari Pasaman Tahan Mantan Walinagari Koto Kaciak Bonjol Tekait Apa. Berita Online. (https://sumbar.antaranews.com/berita/214701/kejar-pasamantahan-mantan-wali-nagari-koto-kaciak-bonjol-terkait-apa) . Diakses pada tanggal 22 September 2018.

Rochmat Saefudin. (2016). Pengaruh Implementasi Kebijakan Terhadap Kinerja Kelurahan di Kota Banjar. Tesis Program Pascasarjana Universitas Pasundan Bandung.

Ruddy Haryadi. (2015). Pengaruh Implementasi Kebijakan Terhadap Kinerja Pelayanan Publik. Jurnal ilmiah Politea FISIP Universitas Al-Ghifari. 14 (7).

Syamsir. (2017). "Model Pembinaan Kapasitas Aparatur Pemerintahan Nagari dalam Pengelolaan Keuangan Nagari di Kabupaten Tanah Datar Provinsi Sumatera Barat". Laporan Penelitian. Padang: Universitas Negeri Padang.

Tachjan. (2006). Implementasi Kebijakan Publik. Bandung : AIPI Bandung.

Titin Kartini. (2017). Pengaruh Implementasi Kebijakan Terhadap Kinerja Pegawai dalam Mewujudkan Kualitas Pelayanan pada Penyelenggaraan Ibadah Haji dan Umrah di Kementerian Agama. Tesis Program Pascasarjana Universitas Pasundan Bandung. (http://respository.unpas.ac.id/4015/ ) 
Wirawan. (2009). Evaluasi Kinerja Sumber Daya Manusia; teori, aplikasi dan penelitian. Jakarta : Salemba Empat.

UU Nomor 6 Tahun 2014 tentang Desa.

Peraturan Menteri Dalam Negeri Nomor 20 tahun 2018 tentang Pengelolaan Keuangan Desa.

Peraturan Bupati Kabupaten Pasaman Nomor 2 Tahun 2016 tentang Tata Cara Pembagian, Penetapan, Rincian Dana Desa Setiap Nagari dan Perioritas Penggunaan Dana Desa di Kabupaten Pasaman Tahun Anggaran 2016. 